\title{
Pendidikan Toleransi Hidup Beragama di Yapis Papua
}

\author{
Hasrudin Dute \\ SPS Universitas Islam Negeri Jakarta, Indonesia \\ hasruddin_dute18@mhs.uinjkt.ac.id
}

\begin{abstract}
Abstrak:
Tujuan penulisan ini adalah untuk mengetahui hidup beragama peserta didik di lembaga pendidikan Yapis Jayapura. Metode penulisan ini adalah deskriptif kualitatif, dengan pengumpulan data dari beberapa hasil riset penelitian, buku, observasi dan wawancara tentang lembaga pendidikan Islam Yapis Papua. Hasil penulisan ini menunjukkan bahwa pendidikan toleransi beragama telah diterapkan di lembaga pendidikan Yapis Papua. Karena gagasan mengenai toleransi beragama bukanlah hal yang sulit, karena ajaran dari masing masing agama khususnya Islam mengajarkan tentang saling mengakui dan menghormati pihak lain, perbedaan dalam sisi bahasa, budaya agama bahkan etnis dapat diterima dan harus diterima sebagai sunnatullah, sebagai hal yang baik yang datang nya dari Allah.
\end{abstract}

Kata Kunci: Pendidikan, Toleransi, Hidup Beragama.

\begin{abstract}
:
The purpose of this paper is to find out the religious life of students at the Yapis Jayapura educational institution. This writing method is descriptive qualitative, with data collection from several research results, books, observations and interviews about the Yapis Papua Islamic educational institutions. The results of this paper indicate that religious tolerance education has been implemented in Yapis Papua educational institutions. Because the idea of religious tolerance is not difficult, because the teachings of each religion, especially Islam teaches about mutual recognition and respect for other parties, differences in terms of language, religious culture and even ethnicity can be accepted and must be accepted as sunnatullah, as good things that come it's from Allah.
\end{abstract}

Keywords: Education, Tolerance, Religious Life. 


\section{Pendahuluan}

Keinginan kemajuan dalam kehidupan manusia dan hidup berdampingan sesama manusia lainnya demi melakukan pelestarian dan pengalihan serta pengembangan kehidupan manusia melalui pendidikan. Proses muncul dan pertumbuhan masyarakat, kehadiran pendidikan senantiasa menjadi perhatian utama dalam rangka memajukan makhluk ciptaan Allah yang dari satu fase ke fase berikutnya akan senantiasa sejalan dengan tuntutan dan harapan masyarakat.

Manusia adalah makhluk ciptaan Allah yang membawa fitrah yang dapat memberikan pengajaran serta sekaligus dapat juga diajar. ${ }^{1}$ Potensi fitrah ${ }^{2}$ ini harus dijaga dan dikembangkan sehingga dapat menjadi baik serta tetap menduduki kedudukan sebagai khalifah makhluk Tuhan yang mulia. Mengembangkan potensi dasar ini harus melalui serangkaian proses di dalam pendidikan. ${ }^{3}$

Pendidikan agama Islam sebagai satuan ilmu yang diajarkan di sekolah lembaga pendidikan Yapis Papua memainkan peran dalam menjadikan siswa sebagai makhluk Tuhan sekaligus hamba yang beriman dan beramal shaleh sesuai dengan cita-cita dan tujuan diciptakan manusia peduli terhadap kelompok yang berbeda dengan kelompoknya.

Pendidikan agama Islam yang diajarkan di sekolah dan lembaga pendidikan berisikan tentang akidah, ibadah, fikih, sejarah dan akhlak serta pengabdian kepada Tuhan Yang Maha Kuasa yang tulus dan memberikan cara dan jalan di dalam menjalankan rutinitas ibadah agar menjadi siswa yang taat, dapat mengamalkan apa yang dipelajari dalam kehidupan sehari-hari di samping itu pula harus bersikap sopan santun kepada sesama, bersikap toleran akan hak-hak yang dimiliki oleh sesama manusia.

Dimensi afektif atau sikap moral menjadi penilaian siswa di sekolah di samping penilaian psikomotorik dan kognitif, merupakan sasaran utama dari sistem pendidikan agama Islam. Sebab moral merupakan pangkal dari tingkah laku manusia dalam menjalankan segala aktivitasnya. Kesalahan dalam membentuk moral, akan berdampak pada kesalahan-kesalahan keputusan yang diambil manusia. Dengan pendidikan yang mengedepankan ajaran moral khususnya keagamaan, akan membentuk paradigma dan tindakan yang mengarah pada

\footnotetext{
${ }^{1}$ Abuddin Nata, Ilmu Pendidikan Islam (Cet. 1; Jakarta: Prenada Media Group, 2010), h. 177.

${ }^{2}$ Yang berarti mengadakan dan menciptakan, Fitrah Allah pada manusia berarti pengadaan dan penciptaan yang dilakukan Allah terhadap manusia dalam suatu jenis ciptaan tertentu yang memungkinkannya untuk melakukan suatu perbuatan atau mencapai suatu tujuan tertentu. Lihat al-Raghib al-Ishfahani>, Mu'jam Mufradat alfazh al-Qur'an (Beirut: Dar al-Fikr, tth), h. 396.

${ }^{3}$ Baharuddin dan Moh. Sakin, Pendidikan Humanistik (Ar-Ruzz Media: Jogjakarta, 2007), h. 101.
} 
terkontrolnya segala tindakan dari dekadensi yang akan berakibat fatal. Paradigma harus disandarkan pada nilai-nilai keagamaan, sehingga segala aktivitas siswa berjalan sesuai dengan tuntunan Tuhan.

Proses pendidikan tertuang dalam sistem pendidikan nasional nomor 20 tahun 2003 pada Bab I pasal 1 ayat 1pendidikan adalah usaha sadar dan terencana untuk mewujudkan suasana belajar dan proses pembelajaran agar peserta didik secara aktif mengembangkan potensi dirinya untuk memiliki kekuatan spiritual keagamaan pengendalian diri, kepribadian, kecerdasan, akhlak mulia, serta keterampilan yang diperlukan dirinya, masyarakat, bangsa dan negara. Pemerintah berusaha mengembangkan potensi yang dimiliki oleh setiap peserta didik agar dapat menjadi manusia yang baik, taat dan unggul dalam hal keduniaan juga dalam hal akhirat, tertuang dalam sistem pendidikan nasional no. 20 tahun 2003 pada Bab II Pasal 3.

Persoalan kemajemukan merupakan tantangan utama yang dihadapi oleh agama-agama di dunia ini mengingat setiap agama hadir dari kebudayaan dan lingkungan yang plural. Pada saat yang sama pemeluk agama membentuk wawasan keagamaan mereka yang bersifat tertutup eksklusif dan bertentangan dengan semangat multikultur.

Semua keyakinan agama yang dipeluk oleh manusia diyakini secara normatif dan doktriner senantiasa mengajarkan prinsip kebaikan kasih sayang dan toleransi. Namun praktiknya pengamalan doktrin kitab suci terkait wacana missioner ini tak jarang menimbulkan gesekan, baik berupa sengketa dalam skala kecil hingga konflik antar umat beragama yang bermuara pada persoalan claim of truth dan claim of salvation di kalangan internal agama itu sendiri. Keadaan ini menggambarkan agama tak lagi membawa kedamaian dan ketentraman, malah sebaliknya terlihat menyeramkan.

Kemajemukan bangsa Indonesia tersebut selain merupakan khazanah kekayaan budaya nasional dan kekuatan bangsa, bisa juga menimbulkan berbagai persoalan. ${ }^{4}$ Toleransi dalam kemajemukan bukan pernyataan bahwa semua agama sama sama benar. Namun, pendidikan toleransi hidup beragama di lembaga pendidikan adalah pengajaran terhadap peserta didik untuk bersedia menerima kenyataan bahwa memang ada cara dan gaya hidup, berbudaya, dan berkeyakinan agama yang berbeda. Dalam kesediaan tersebut peserta didik akan bekersama sama, hidup, berintegrasi di dalam membangun dan mempertahankan Negara. Frans Magnis Suseno mengatakan toleransi hidup beragama adalah syarat wajib agar Negara Indonesia dapat

\footnotetext{
${ }^{4}$ Abd. Rachman Assegaf, Filsafat Pendidikan Islam (Cet. 1; Jakarta: PT RajaGrafindo Persada, 2011), h. 309. 
bersatu, dan Negara ataupun bangsa yang tidak menghargai toleransi beragama adalah bangsa yang dapat membinasakan diri sendiri.

Salah satu persoalan utama dalam pembangunan di Indonesia, khususnya di kota Jayapura Papua salah satunya adalah terletak pada pembangunan, kesehatan dan pelayanan pendidikan tentunya akan berpengaruh pada aktifitas-aktifitas lain yang juga sangat berpengaruh kualitas sumber daya manusia (SDM). Padahal, ini merupakan kunci utama dalam roda pembangunan, pelayanan publik dan pemerintahan maupun di sektor swasta. Oleh karena itu masyarakat dalam hal ini siswa, harus diberikan pendidikan toleransi hidup beragama yang dapat menunjang pembangunan, tujuannya adalah menjadi subyek yang aktif dan sehat yang menjunjung tinggi etika, moral dan nilai-nilai pluralisme. ${ }^{5}$

Salah satu dari tujuan pendidikan yang dilakukan oleh pemerintah melalui lembaga pendidikan negeri maupun swasta adalah tidak mengenal kelas sosial ${ }^{6}$ kemasyarakatan, karena pendidikan multicultural adalah sebuah system pendidikan yang berupaya untuk meredam kesenjangan sosial, kecemburuan sosial, dengan mengenalkan kebersamaan dan saling menghargai di dalam perbedaan.

Pembelajaran pendidikan agama Islam yang masuk dalam sistem pendidikan nasional sekarang ini bukanlah pendidikan yang semata-mata berorientasi pada siswa, tetapi ada sebuah kepentingan nasional dalam Undang-Undang Nomor 20 tahun 2003. Sepertinya berat bagi dunia pendidikan khususnya pendidikan agama Islam untuk mewujudkan cita-cita nasional mewujudkan harmonisasi dalam kehidupan keberagamaan. Hal ini disebabkan karena penerapan pembelajaran bidang studi pendidikan agama Islam diperhadapkan pada kurangnya alokasi waktu pembelajaran pendidikan agama, kualitas sumber daya guru yang belum optimal, adanya anggapan bahwa hal-hal yang berhubungan dengan bidang studi pendidikan agama Islam adalah tanggung jawab guru agama sehingga guru yang lain merasa tidak perlu untuk terlibat, begitu pula kurangnya keterlibatan masyarakat. Belum lagi praktek pembelajaran pendidikan agama islam di sekolah lebih menekankan pada ranah kognitif dan pertumbuhan kesadaran nilai-nilai agama yang berakibat terjadinya kesenjangan antara pengetahuan dan pengamalan nilai-nilai agama sehingga pendidikan agama berubah menjadi pengajaran agama yang tidak berorientasi pada pembentukan pribadi-pribadi muslim. ${ }^{7}$

\footnotetext{
${ }^{5}$ Wawan H. Purwanto, Papua 100 tahun Ke Depan (Cet. 1; Jakarta: Cipta Mandiri Bangsa, 2010), h. 143. ${ }^{6}$ Kelas Sosial adalah suatu lapisan orang orang yang berkedudukan satu dalam satu status sosial. Sudjangi, "Pluralitas Sosial, Hubungan Antar Kelompok Agama dan Kerukunan" Harmoni: Jurnal Multikultural dan Multireligius, Vol. 2 No. 5, Puslitbang Kehidupan Beragama Depag RI, Jakarta 2003, h. 15.

${ }^{7}$ Liustia, dkk. Problematika Pendidikan Agama di Sekolah, Hasil penelitian tentang Pendidikan Agama di Kota Jogjakarta, 2004-2006 (Jogjakarta: Interfedei, 2007), h. 207-209.
} 
Berdasarkan uraian yang dikemukakan, maka perlu dikaji penerapan pembelajaran pendidikan agama Islam yang bernuansa toleransi hidup beragama yang diterapkan di lembaga pendidikan Islam Yapis Papua Jayapura. Metode penulisan ini adalah deskriptif kualitatif, dengan pengumpulan data lapangan melalui observasi dan juga dari sumber sekunder yaitu beberapa hasil riset penelitian, buku yang berkaitan dengan lembaga pendidikan Islam Yapis Papua.

\section{Pembahasan}

\section{Pendidikan Agama Islam}

Langeveld mengatakan pengaruh pendidikan itu datangnya dari orang yang sudah besar (atau yang dibuat oleh orang besar diantaranya buku, lingkungan sekolah, aktivitas sehari hari, dan lainnya) dan diberikan kepada orang yang yang belum besar. Ahmad D. Marimba dalam Hasbullah mengatakan pendidikan adalah pimpinan atau bimbingan secara sadar oleh si pengajar terhadap perkembangan rohani dan jasmani peserta didik dalam membentuk pribadi yang utama. ${ }^{8}$

Ki Hajar Dewantara mengatakan pendidikan adalah tuntunan di dalam hidup tumbuhnya anak-anak, ${ }^{9}$ perspektif sosiologi mengartikan pendidikan sebagai usaha timbal balik dari tiap individu manusia dalam penyesuaian dirinya dengan individu manusia lainnya dan dengan alam sekitar. ${ }^{10}$ Sedangkan dalam perspektif psikologi, pendidikan dapat dimaknai sebagai upaya individu manusia untuk memupuk kepribadiannya sesuai dengan norma dan nilai yang terjadi di masyarakat. ${ }^{11}$ Sahal Mahfud dalam M. Bashori Muchsin menyatakan bahwa pendidikan pada hakikatnya adalah usaha yang dilakukan membentuk watak dan perilaku secara tersistem, tertuju dan terencana. ${ }^{12}$ Quraish Shihab menjelaskan arti dari agama sebagai hubungan antara makhluk dan khalik-Nya. Hubugan ini terwujud dalam sikap batinnya serta tampak dalam ibadah yang dilakukannya dan tercermin pula dalam sikap kesehariannya. ${ }^{13}$ Agama Islam sebagai agama Allah swt. adalah jalan hidup yang ditetapkan oleh Allah swt. sebagai sumber kehidupan, yang harus dilalui (ditempuh) oleh manusia, untuk kembali atau menuju kepada-Nya. ${ }^{14}$

\footnotetext{
${ }^{8}$ Hasbullah, Dasar-dasar Ilmu Pendidikan (Jakarta: PT Raja Grafindo Persada, 2009), h. 3.

${ }^{9}$ Suwarno, Pengantar Umum Pendidikan (Jakarta: Aksara Baru, 1985), h. 2.

${ }^{10}$ Zuhairini, dkk., Filsafat Pendidikan Islam (Cet. 5; Jakarta: Bumi Aksara, 2010), h. 150.

${ }^{11}$ Tim Dosen FKIP-IKIP Malang, Pengantar Dasar-Dasar Pendidikan (Surabaya: Usaha Nasional, 1988), h. 2.

${ }^{12}$ M. Bashori Muchsin dkk., Pendidikan Islam Humanistik (Cet. 1; Bandung: Refika Aditama, 2010), h. 3.

${ }^{13}$ M. Quraish Shihab, Membumikan al-Qur'an (Bandung: Mizan, 2002), h. 209-210.

${ }^{14}$ Abdurrahman an-Nahlawi, Pendidikan Islam di Rumah, Sekolah dan Masyarakat (Jakarta: Gema Insani, 2005), h. 24. 170 | IQ (Ilmu Al-qur'an): Jurnal Pendidikan Islam | Volume 2 No. 022019
} 
Pendidikan agama Islam sering disebut dengan istilah tarbiyah, ta'lim dan ta'dib. Ketiganya didefinisikan sebagai pendidikan.

1) Al-Tarbiyah. Dalam mu'jam bahasa Arab, kata al-tarbiyah memiliki tiga akar kebahasaan yaitu:

a) Rabba-yarbu tarbiyatan, yang memiliki makna (zaad) tambah, dan (namaa) berkembang. Arti dari pendidikan merupakan proses tambah dan pengembangan apa yang dimiliki dan ada diri peserta didik baik secara psikis, psikis, fisik maupun secara spiritual dan sosial.

b) Rabba-yurbi-tarbiyatan, yang memiliki makna (nasya'a) tumbuh, dan menjadi lebih dewasa dan besar. Pendidikan diartikan adalah usaha didalam menumbuhkan dan mendewasakan peserta didik baik secara fisik maupun mental spiritual.

c) Rabba-yarubbu-tarbiyatan, yang memiliki makna (ashlaha) memelihara, memperbaiki, memberi makna, merawat, menjaga kelestarian, menjaga eksistensinya, menguasai urusan, memperindah. ${ }^{15}$

Jika ketiga kata tersebut digabungkan maka akan memperoleh pengertian bahwa altarbiyah berarti sebuah proses menumbuh dan mengembangkan potensi (fisik, intelektual, sosial, estekika dan spiritual) yang terdapat pada siswa sehingga dapat tumbuh dan terbina dengan optimal melalui cara memelihara, mengasuh, merawat, memperbaiki dan mengaturnya secara terencana, sistematis dan berkelanjutan.

2) Al-Ta'lim

Kata ta 'lim yang jamaknya ta 'alim berasal dari kata dasar 'ilm yang berarti menangkap hakekat sesuatu. Ta'lim. Quraish Shihab, ketika mengartikan kata yu'allimu sebagaimana terdapat pada surat al-Jumu'ah/62: 2 dengan arti mengajar yang intinya tidak lain kecuali memenuhi dan mengisi benak anak didik dengan pengetahuan yang berkaitan alam fisika atau metafisika. ${ }^{16}$ Hans Weber mengatakan dapat berarti pendidikan, pelatihan, pembelajaran, perintah, nasehat, pemberitahuan tentang sesuatu. ${ }^{17}$

Kata al-ta'lim dalam arti pendidikan merupakan kata yang paling lebih dahulu digunakan daripada kata al-tarbiyah. Kegiatan pendidikan dan pengajaran yang pertama kali dilakukan o,leh Nabi Muhammad saw. di rumah sahabat nabi al-Arqam di Mekkah. Kata ta 'lim termasuk kata yang yang paling tua dan banyak digunakan dalam kegiatan bukan formal

\footnotetext{
${ }^{15}$ Abdul Mujib dan Jusuf Mudzakir, Ilmu Pendidikan Islam (Cet. 1; Jakarta: Prenada Media, 2006), h. $10-11$

${ }^{16}$ M. Quraish Shihab, Membumikan al-Qur'an (Cet. 2; Bandung: Mizan, 2007), h. 92.

${ }^{17}$ Hans Wehr, Mu'jam al-Lughah al-Arabiyah al-Mu'asharah (A Dictionary of Modern Written Arabic) (Beirut Librarie Du Liban \& London: Macdonald \& Evans LTD, 1974), h. 324.
} 
dengan tekanan utama pada pemberian wawasan, pengetahuan atau informasi yang bersifat kognitif. al-ta 'lim lebih pas diartikan pengajaran daripada diartikan pendidikan.

3) Al-Ta'dib

Kata al-ta'dib akar kata dari dari kata addaba, yuaddibu, ta'diban dapat berarti pendidikan, disiplin, patuh dan tunduk pada aturan), peringatan atau hukuman, hukumanpenyucian. Kata $a l$-ta'dib juga, berasal dari kata adab yang berarti beradab, bersopan santun, tata krama, adab, budi pekerti, akhlak, moral dan etika. Melalui kata al-ta'dib ini pendidikan sebagai sarana pemberian nilai akhlak mulia yang berasal dari ajaran yang agama, serta menjadi proses integrasi ilmu pengetahuan.

Garis besar program pengajaran PAI di sekolah umum, dijelaskan bahwa pendidikan agama di sekolah adalah usaha sadar untuk menyiapkan siswa dalam menghayati, memahami, meyakini, dan menerapkan agama Islam melalui kegiatan latihan, pengajaran dan bimbingan dengan memperhatikan tuntutan untuk menghormati agama orang lain kaitannya dengan kerukunan antarumat beragama demi mewujudkan persatuan Indonesia. ${ }^{18}$ Pendidikan agama Islam pada hakikatnya merupakan sebuah proses, dalam pengembangannya juga sebagai rumpun mata pelajaran yang diajarkan di sekolah maupun perguruan tinggi. ${ }^{19}$

Pelajaran pendidikan agama Islam ini jelas dituntut kepatuhan mengikuti aturan dan kewajiban agama yang dianutnya. Siswa akan belajar untuk membedakan perbuatan yang baik dan yang buruk. Pelajaran agama akan memberikan pengertian akan norma-norma kehidupan, memupuk rasa bersyukur, puas, toleransi, serta disiplin. Dalam pelajaran agama, seorang siswa juga diarahkan pada pertanggung jawaban individual sekaligus sebagai anggota masyarakat. Dalam agama seseorang akan memperoleh dari apa yang dikerjakan. ${ }^{20}$ Haidar Putra Daulay, mengemukakan pendidikan agama Islam yang bertujuan untuk membentuk pribadi muslim seutuhnya, mengembangkan seluruh potensi manusia, baik yang berbentuk jasmani, maupun rohani. $^{21}$

Paling tidak ada empat unsur pokok secara bahasa dan istilah untuk menunjukkan pengertian dari PAI yaitu: 1) manusia sebagai objek dari pendidikan, hal ini tidak lain karena pendidikan untuk meningkatkan sumber daya manusia. 2) Siswa hendak disiapkan untuk mencapai tujuan; dalam arti ada yang dibimbing, diajari dan/atau dilatih dalam peningkatan

\footnotetext{
${ }^{18}$ Muhaimin, dkk., Paradigma Pendidikan Islam (Cet. 4; Bandung: Rosda Karya, 2008), h. 76.

${ }^{19}$ Departemen Agama RI. Dirjen Kelembagaan Agama Islam Ditpais, Pedoman Pendidikan Agama Islam untuk Sekolah Umum (Jakarta: Diptais, 2004), h. 2.

${ }^{20}$ Indra Djati Sidi, Menuju Masyarakat Belajar Menggagas Paradigma Baru Pendidikan (Jakarta: Paramadina, 2001), h. 106.

${ }^{21}$ Haidar Putra Daulay, Pendidikan Islam (Jakarta: Kencana, 2004), h. 153. 172 | IQ (Ilmu Al-qur'an): Jurnal Pendidikan Islam | Volume 2 No. 022019
} 
keyakinan, pemahaman, penghayatan dan pengamalan terhadap ajaran Islam. 3) memberikan nilai-nilai akhlak kepada manusia. Peningkatan nilai nilai yang baik diringi dengan potensi manusia yang lain yaitu perbuatan, perasaan dan akal. 4) Kegiatan pembelajaran PAI diarahkan untuk meningkatkan pengetahuan, keyakinan, dan penerapan ajaran agama siswa, selain itu untuk membentuk kesalehan sosial dan juga kesalehan individu. Dalam arti, kesalehan individu diharapkan dapat menular melalui hubungan keseharian dengan individu lainnya baik yang seiman maupun yang tidak seiman

\section{Toleransi Hidup Beragama}

Toleransi di definisikan di dalam kamus umum bahasa Indonesia sebagai sikap menenggang (menghargai, membiarkan, membolehkan) pendirian (pendapat, pandangan, kepercayaan, kebiasaan, kelakuan dan lain sebagainya) yang lain atau bertentangan dengan pendiriannya sendiri seperti agama, ideologi dan lain-lain. Ada dua model pendidikan toleransi beragama, yaitu: Pertama, pendidikan toleransi beragama pasif, yakni pemberian pemahaman akan sikap menerima perbedaan sebagai sesuatu yang bersifat faktual. Kedua, pendidikan toleransi beragama yang aktif, bukan saja mengakui adanya perbedaan namun juga terlibat di dalam kegiatan kegiatan dengan agama lain di tengah perbedaan dan keragaman. Toleransi aktif merupakan ajaran semua agama. Hakikat pendidikan toleransi beragama adalah hidup berdampingan secara damai dan saling menghargai di antara keragaman.

Praktek pendidikan toleransi di Indonesia, mengalami turun naik, pasang surut yang disebabkan oleh pemahaman mengenai mereka dan kita. Adanya ekstrimis yang merupakan pakaian kekerasan yang diakibatkan pada pemahaman yang anti dialog dan terkesan eksklusif terhadap teks keagamaan. Pendidikan toleransi beragama adalah pembelajaran mengenai sikap saling menghormati, saling menghargai, dan sikap saling menerima di tengah keragaman budaya, suku, agama dan kebebasan berekspresi. Dengan adanya pendidikan toleransi beragama ini maka suatu komunitas dapat hidup berdampingan secara damai, rukun, dan bekerja sama dalam mengatasi berbagai permasalahan sosial yang terjadi di sekitarnya.

Konsep toleransi hidup beragama menurut Abdullah dalam Simuh, terdapat dua macam penafsiran, yaitu: (1) klaim bahwa toleransi hanya menuntut pihak lain beradaptasi atau penyesuaian. (2) klaim bahwa toleransi lebih membutuhkan dari pada itu, yakni membutuhkan bantuan, peningkatan dan pengembangan. ${ }^{22}$

Nilai-nilai toleransi hidup beragama yang dapat dijadikan pijakan adalah sebagai berikut:

\footnotetext{
${ }^{22}$ Simuh dkk., Islam dan Hegemoni Sosial (Cet. 1; Jakarta: Mediacita, 2001), h. 74-75.
} 
a. Saling menahan diri terhadap ajaran keyakinan, dan kebiasaan golongan agama lain yang berbeda atau mungkin berlawanan dengan ajaran, keyakinan dan kebiasaan sendiri.

b. Sikap saling menghormati hak orang lain untuk menganut dengan sungguh-sungguh keyakinan agamanya.

c. Sikap saling mempercayai atas i’tikad baik golongan agama lain

Konsep toleransi hidup beragama hanya mengisyaratkan pengakuan atas kehadiran budaya lain, kebudayaan yang berbeda dari kebudayaan setempat. Dalam komunitas beragama Islam, ajaran yang seringkali dikemukakan, direproduksi untuk mengakui dan menegaskan konsep toleransi beragama ini adalah bagimu agamamu, bagiku agamaku. Kehadiran aneka kebudayaan dianggap sebagai sebuah kontak yang tidak akan mempengaruhi kemurnian masing-masing agama.

\section{Toleransi beragama dalam Pendidikan Agama Islam}

Toleransi dalam pendidikan agama Islam mencakup lima prinsip yaitu sebagai berikut:

a. Cinta. Toleransi bukan hanya sekadar menerima adanya perbedaan, tetapi ikut aktif terlibat di dalam khazanah perbedaan tersebut, sehingga dalam sikap tingkah laku muslim, cinta mendahului segalanya. Bahkan, harus mampu mengurangi perbedaan dalam hal sosial, bukan sebaliknya, perbedaan sosial menyebabkan hilangnya cinta.

b. Fitrah. Toleransi sejati mengakui bahwa perbedaan adalah bentuk dari fitrah dan kehendak Allah, sehingga mustahil bagi seorang muslim untuk memaksakan kehendaknya agar seluruh manusia berada dalam keseragaman karena sikap seperti ini berarti melawan fitrah tersebut.

c. Keterbukaan. Pemutlakan agama hanya diprioritaskan ke dalam diri agar mampu menjalankan syariat agama secara kaffah. Sebaliknya, sikap keluar adalah relatif. Dalam Q.S. al-Qalam/68: 40 disebutkan

$\cap \subseteq \supset \cup\left\lfloor\Lambda \mid \notin \subseteq \psi \square \psi 7 \notin 9 \equiv \xi \square \in / \mathrm{O} \Downarrow_{\gamma} \square \square \rho \& \int \mathrm{O} \Downarrow_{\gamma}\right\rceil=\psi \square$ Tanyakanlah kepada mereka: "Siapakah di antara mereka yang bertanggung jawab terhadap keputusan yang diambil itu?"23

Dalam QS. Al-Muddas \}ir/74: 38.

$$
\cap \subset \nabla \cup(\pi \mathrm{o} \Psi \square \notin \delta \mathrm{u} \square|\mathrm{M} \tau \sigma| \Upsilon \xi . \exists \psi \vartheta \in / / \%) \square \tau \mathrm{P} \square \cong^{\mathrm{TM}} .
$$

Tiap-tiap diri bertanggung jawab atas apa yang telah diperbuatnya.

d. Aktual. Bentuk toleransi harus tampak aktual menunjukkan semangat rahmatan li al'alamin, sehingga kehadiran seorang muslim dimana pun dia berada memberikan rasa damai sejahtera kepada lingkungannya secara nyata, jujur dan keluar dari nurani yang paling dalam. Muslimin harus tampil sebagai tali pengikat persaudaraan dalam landasan saling

\footnotetext{
${ }^{23}$ Departemen Agama, Al-Qur'an dan Terjemahnya dengan Tranliterasi Arab-Latin op. cit., h. 1160. 174 | IQ (Ilmu Al-qur'an): Jurnal Pendidikan Islam | Volume 2 No. 022019
} 
menghargai sebagaimana dicontohkan Rasulullah pada piagam madinah dan Umar bin Khattab dengan piagam aelia.

e. Bertangung jawab. Toleransi harus bermuatan tanggung jawab dan memandang kebersamaan dengan orang lain justru adalah citra diri manusia, sehingga toleransi memberikan kerangka acuan; bukan sebagai kewajiban, tetapi sebuah kebutuhan.

Dengan asumsi atas sikap toleransi hidup beragama yang dipersepsi oleh setiap muslim sebagai fitrah maka kewajiban setiap muslim untuk mewujudkannya dalam sikap dan tindakan. Bahkan, kewajiban setiap muslim untuk menunjukkan kepada dunia bahwa dirinya adalah sosok postur manusia yang mendahulukan cinta dari benci, merefleksikan sayang dari amarah.

Dalam bentuk aktual, hablun mina al-nas berarti menampilkan sosok muslim sebagai khalifah fi al-ard\}i yang membawa amanah as-salam, melalui kekuatan akhlak yang disemangati oleh jiwa yang penuh dengan kasih (qalbun salim) dan memandang manusia sebagai bagian dari alam ciptaan Allah swt. yang harus didekati dengan rasa mahabbah.

\section{Dasar-Dasar Toleransi hidup beragama}

\section{a. Ta'aruf atau Saling Kenal Mengenal}

Dalam surat al-Hujurat/49: 13 disebutkan:

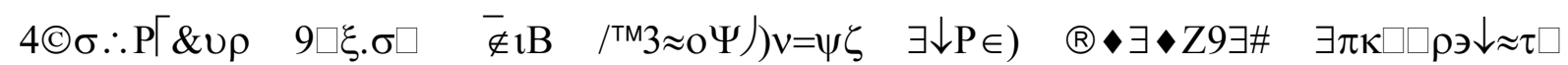

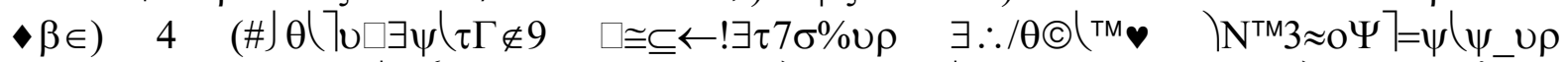
$\left.\cap \supseteq \subset \cup \cdot \square \square \in 7 \psi \zeta\left(\Lambda\left(\in=\tau(\bullet ! \exists \# \bullet \beta \in) 4 \backslash \mathrm{N}^{\mathrm{TM}} 39 \sigma\right)\right) ? \rho \& \leftrightarrow ! \exists \# \psi \square \Psi \notin \subset\right) /{ }^{\mathrm{TM}} 3 \tau \mathrm{B} \tau \square \int 2 \rho \&$ Hai manusia, sesungguhnya Kami menciptakan kamu dari seorang laki-laki dan seorang perempuan dan menjadikan kamu berbangsa - bangsa dan bersuku-suku supaya kamu saling kenal-mengenal. Sesungguhnya orang yang paling mulia di antara kamu di sisi Allah ialah orang yang paling takwa di antara kamu. Sesungguhnya Allah Maha Mengetahui lagi Maha Mengenal. ${ }^{24}$

Dari ayat ini setidaknya ada dua hal yang dapat kita tarik. Pertama, pada mulanya manusia itu satu, yang menjadikan manusia berbangsa-bangsa dan bersuku-suku ialah Tuhan, dan yang mengukur kemuliaan ialah Tuhan. Jadi ada lingkaran yang berawal dan berakhir pada Tuhan, teosentrisme. Kedua, manusia secara objektif memang berbangsa-bangsa dan bersukusuku. Manusia itu secara ontologis (berdasarkan kenyataan) memang makhluk sosial, sehingga mereka berkelompok dalam bangsa dan suku.

Pengelompokan dan solidaritas dipandang oleh Al-Qur'an sebagai sunnatullah yang tak akan berubah. Tujuan dari pengelompokan itu adalah saling kenal mengenal. Ta'aruf berasal dari kata 'arafa yang berarti mengerti. Orang diharapkan untuk mengerti kepentingan orang lain, sehingga dapat menenggang. Itulah prinsip resiprositas (timbal balik) yang terjadi, saling mengerti kepentingan orang lain. Dalam masyarakat (sekolah), semua warga sekolah

\footnotetext{
${ }^{24}$ Departemen Agama, Al-Qur'an dan Terjemahnya dengan Tranliterasi Arab-Latin, h. 1041.
} 
harus mengerti kepentingan, baik horizontal maupun vertikal orang lain, sehingga hak-hak orang lain tidak dilanggar. ${ }^{25}$

Ta'aruf hanya berjalan kalau ada persamaan atau equality. Tidak ada warga negara kelas dua. Ta 'aruf juga berarti adanya komunikasi dialogis. Tidak ada dominasi satu kelompok atas kelompok lain. Semua perkara diselesaikan berdasarkan kepentingan semua. Dialog dapat mencegah konfrontasi dan konflik sosial.

b. Ta'awun atau Kerja Sama

Dalam QS. Al-Maidah/5: 2 disebutkan

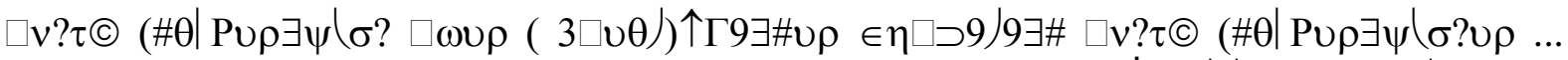
$\cap \not \subset \cup \ldots . \cup \beta \equiv \cup \rho \mid \square @(19 \exists \# \cup \rho \supset \mathrm{O}) \mathrm{OM}\} \exists \#$

... dan tolong-menolonglah kamu dalam (mengerjakan) kebaikan dan takwa, dan jangan membantu bahu membahu dalam berbuat dosa dan pelanggaran. .. ${ }^{26}$

Ada dua kepentingan yang diharuskan untuk bekerjasama, yaitu kepentingan manusia dan kepentingan Tuhan.

c. Ukhuwah dan Hubungan Islam dengan Agama Lain di Yapis Papua

Ukhuwah merupakan salah satu konsep fundamental dalam Islam yang di dalamnya juga terangkum masalah hubungan Islam dengan agama lain juga dalam hal toleransi. Konsep ukhuwah diartikan dengan persamaan dan keserasian dalam banyak hal. Persamaan dalam sifat-sifat juga menyebabkan persaudaraan. Sehingga ukhuwah dapat diwujudkan jika ada persamaan-persamaan di antara sesama manusia. Persamaan agama dapat menyebabkan persaudaraan. Kendati demikian semua itu tidak men-jamin sepenuhnya, sebab tidak jarang antara sesama pemeluk agama dan antar sesama aliran juga terjadi pertikaian.

Quraish Shihab menjelaskan beberapa pengertian ukhuwah sebagai berikut: pertama, ukhuwwah fi al-ubudiyyah, yaitu bahwa seluruh makhluk adalah bersaudara dalam arti memiliki persamaan sama sama punya hak untuk belajar sekalipun lembaga pendidikan yang menaunginya adalah lembaga pendidikan ciri khas agama seperti halnya lembaga pendidikan Yapis Papua. Persamaan ini antara lain dalam ciptaan dan kedudukan kepada Allah, yakni bahwa semua makhluk tunduk dan patuh kepada khalik. Kedua, ukhuwah fi al-insaniyyah, dalam arti seluruh umat manusia adalah bersaudara. Ketiga, ukhuwah fi al-wathaniyyah wa al$n a s a b$, persatuan dalam kerukunan dan kebangsaan seperti yang diisyaratkan dalam surat alA'raf/7: 65. Keempat, ukhuwah fi al-din al-Islam, persaudaraan antar sesama muslim seperti bunyi ayat surat al-Ahzab/33: 46-48 dan surat al-Hujurat/49: 10.

\footnotetext{
${ }^{25}$ Kuntowijoyo, Identitas Politik Umat Islam (Cet. 2; Bandung: Mizan, 1997), h. 93.

${ }^{26}$ Departemen Agama, Al-Qur'an dan Terjemah Departemen Agama dengan Transliterasi Arab-Latin op. cit. h. 200. 176 | IQ (Ilmu Al-qur'an): Jurnal Pendidikan Islam | Volume 2 No. 022019
} 
Hakikat Islam sejalan dengan semangat kemanusiaan universal, maka sudah barang tentu bahwa pikiran yang dikehendaki oleh Islam adalah suatu sistem yang menguntungkan semua orang, termasuk mereka yang bukan muslim. Islam menganjurkan agar para pemeluk mencari titik singgung dan titik temu, tidak saja antar sesama muslim, tetapi terhadap non muslim seperti difirmankan dalam Q.S. ali Imran/3: 64.

d. Adanya Titik Temu Agama-Agama di Pendidikan Agama Islam

Ketika Islam datang dimana masyarakat telah hidup dalam lingkungan budaya dan agama yang sangat plural. Kemajemukan itulah yang membuat Al-Qur'an kemudian menawarkan konsep kalimatun sawa' antar berbagai unsur komunitas dan agama. perbedaan teologis tertentu dibiarkan menjadi milik agama atau kepercayaan sendiri-sendiri, tetapi aspekaspek yang bisa atau mungkin dicari titik temunya didialogkan. ${ }^{27}$ Al-Qur'an menyatakan dalam surat Ali-Imran/3: 64

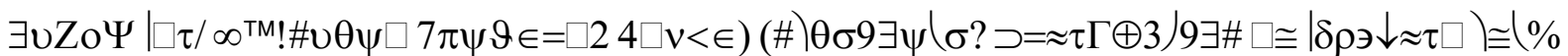
$\square \omega \cup \rho \exists \therefore \leftrightarrow) \square \xi \boldsymbol{-} \notin \mu \in \in / \xi 8 \in \square|\geq(\Sigma \square \omega \nu \rho \vee ! \exists \# \square \omega \in) \psi \square| 7 \| \tau \mathrm{P} \square \omega \rho \&)^{\text {TM}} 30 Z \mid \square \tau / \nu \rho$

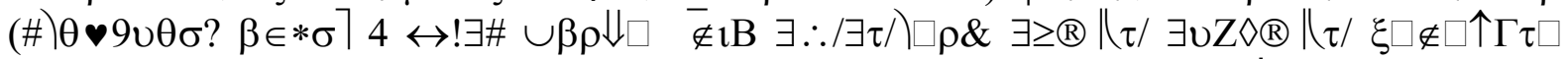
$\cap \notin \subseteq \cup \square \chi \theta \downarrow \vartheta \in=\Upsilon \Upsilon \odot \mathrm{B} \exists \downarrow P \rho \ni \in /\left(\# \rho \downarrow \square \psi \gamma \mid \vee \exists \#\left(\# \theta^{\mathrm{TM}} 9 \theta \diamond\right) \sigma\right]$

Katakanlah: "hai ahli kitab, marilah (berpegang) kepada suatu kalimat (ketetapan) yang tidak ada perselisihan antara kami dan kamu, bahwa tidak kita sembah kecuali Allah dan tidak kita persekutukan Dia dengan sesuatupun dan tidak (pula) sebagian kita menjadikan sebagian yang lain sebagai Tuhan selain Allah". jika mereka berpaling maka katakanlah kepada mereka: "saksikanlah, bahwa kami adalah orang-orang yang berserah diri (kepada Allah)". ${ }^{28}$

Ayat di atas mengisyaratkan adanya titik temu dalam semangat ketuhanan yang barangkali dalam konsteks keindonesiaan adalah apa yang dimaksud dengan Ketuhanan Yang Maha Esa dalam pancasila.

Didasarkan pada semangat di atas, dalam tataran praktis, untuk menjaga keutuhan masyarakat Madinah yang terdiri dari beberapa unsur itu, mula-mula Muhammad menawarkan apa yang disebut piagam madinah. Salah satu poin dari piagam tersebut adalah bagaimana mereka bersatu untuk menangani masalah keamanan dan tatanan hidup bersama. Dalam pandangan umat Islam, Negara Madinah inilah yang dianggap prototipe negara plural.

Menyangkut titik temu agama-agama, ada lima prinsip yang diungkapkan dalam alQur'an yaitu:

1) Al-Qur'an mengajarkan bahwa agama Tuhan adalah universal. Karena Tuhan telah mengutus Rasulullah kepada seluruh umat manusia. Q.S. al-Nahl/16: 36.

\footnotetext{
${ }^{27}$ Moh. Nurhakim, Islam Responsif: Agama di Tengah Pergulatan Ideologi Politik dan Budaya Global (Cet. 1; Malang: UMM Press, 2005), h. 174.

${ }^{28}$ Departemen Agama, Al-Qur'an dan Terjemah Departemen Agama dengan Transliterasi Arab-Latin op. cit. h. 106.
} 


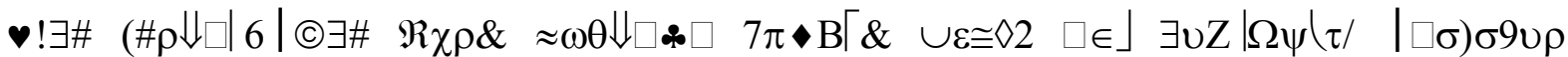
$\left.\left|\varnothing \bullet \mathrm{BN} \downarrow_{\gamma}\right| \Psi \notin \mathrm{B} \cup \rho \wedge ! \exists \# \square \psi \square \psi \delta\left|\cdot \mathrm{BN} \downarrow_{\gamma}\right| \Psi \notin \vartheta \sigma\right\rceil\left(\left|\mathrm{N} \theta^{\mathrm{TM}}\right| \approx \boldsymbol{v} \Leftarrow 9 \exists \#(\# \theta|7 \notin \perp \tau \Gamma|\right.$ $\mid \exists \# \cup \rho$

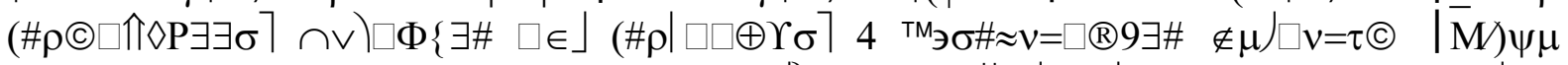
$\cap \subset \notin \cup \square \| \in / \supset \varphi \square \sigma 3 \downarrow \vartheta) 9 \exists \#(\pi \tau 7 \supset) \approx \tau(\square \chi \% \xi$. $\psi \#) \square \xi$.

Dan sungguhnya Kami telah mengutus rasul pada tiap-tiap umat (untuk menyerukan): "sembahlah Allah, dan jauhilah thaghut", maka di antara umat itu ada orang-orang yang diberi petunjuk oleh Allah dan ada pula di antaranya orang-orang yang telah pasti kesesatan baginya. Maka berjalanlah kamu di muka bumi dan perhatikanlah bagaimana kesudahan orang-orang yang mendustakan (rasul-rasul).

2) Al-Qur'an mengajarkan pandangan kesatuan nubuwat (kenabian) dan umat yang percaya kepada Tuhan. Firman Allah: artinya, "sesungguhnya (agama tauhid) ini adalah agama kamu semua agama yang satu dan Aku adalah Tuhanmu, maka sembahlah Aku" QS. Alanbiya/21: 92.

\section{$\mid \mathrm{N} \vee 6 \square / \mathrm{v} \square \quad \mathrm{O} \exists \tau \mathrm{P} \rho \& v \rho \quad \mathrm{Zo} \psi \square \notin \mu \equiv \mathrm{v} \rho \quad \mathrm{Z} \pi \diamond \mathrm{B}\left\lceil \& \quad\left|\mathrm{~N}^{\mathrm{TM}} 3\right| \Phi \diamond \mathrm{B}[\& \quad \square-\subseteq v \supset \square \approx \psi \delta \quad \bullet \beta \in)\right.$} $\cap \circledR \not \subset \cup \Re \chi \rho \downarrow \square|7| \subset \exists \exists \sigma\rceil$ Sesungguhnya (agama Tauhid) ini adalah agama kamu semua; agama yang satu dan aku adalah Tuhanmu, Maka sembahlah aku. ${ }^{29}$

3) Al-Qur'an mempertegas bahwa ajaran agama yang diusung oleh Nabi Muhammad adalah keberlanjutan agama-agama sebelumnya yang secara genealogis paling dekat ialah agama-agama semetik, Abrahamik. Dalam QS. Al-Syura/42: 13.

$\mid \square \notin \% \bullet ! \exists \# \cup \rho \quad \%\left[v \theta \mid \mathrm{P}-\notin \mu \in / \quad 4 \mathbb{C} \square \approx v \rho \quad \exists \tau \mathrm{B} \quad \cup \| \notin \varepsilon \exists ! \exists \# \quad \zeta \notin 1 \mathrm{~B} \quad \mathrm{~N}^{\mathrm{TM}} 3 \sigma 9 \quad \tau\left\{u \square \square^{\circ} *\right.\right.$ 4@ $\left.\left.\psi \square \theta \odot B \cup \rho \quad \tau \Lambda(\notin \delta \equiv \tau \square) / \in) \quad \square-\notin \mu \in / \quad \exists v Z) \square^{\prime} \neq v \rho \quad \exists \tau B v \rho \quad \psi 7\right) \square \sigma 9 \in\right)$ ! $\left.\exists v Z\right) \square \psi \mu \mid \rho \rho \&$

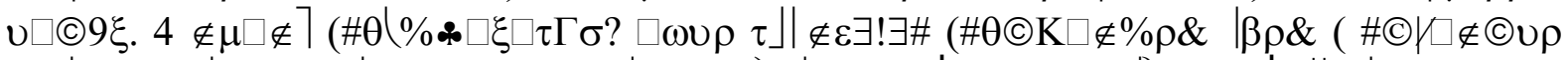

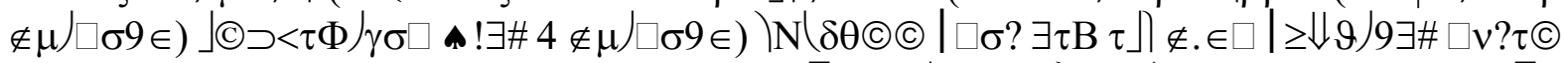
$\cap \supseteq \subset \cup \Leftarrow=\square \notin \perp @ \square \quad \bar{\tau} \mathrm{B} \notin \mu) \square \sigma 9 \in) \backslash \square \notin \square)_{\kappa \nu} \square \nu \rho{ }^{\circledR \top} \mathrm{T} ! \exists \tau \pm \mathrm{o} \square \bar{\tau} \overline{\mathrm{B}}$

Dia telah mensyari'atkan bagi kamu tentang agama apa yang telah diwasiatkan-Nya kepada Nuh dan apa yang telah Kami wahyukan kepadamu dan apa yang telah Kami wasiatkan kepada Ibrahim, Musa dan Isa yaitu: tegakkanlah agama dan janganlah kamu berpecah belah tentangnya. Amat berat bagi orang-orang musyrik agama yang kamu seru mereka kepadanya. Allah menarik kepada agama itu orang yang dikehendaki-Nya dan memberi petunjuk kepada (agama)-Nya orang yang kembali (kepada-Nya). ${ }^{30}$

4) Al-Qur'an memerintahkan umat nabi Muhammad agar menjaga hubungan baik yang telah ada dengan mereka yang beragama lain, khususnya para penganut kitab suci.

Firman Allah dalam Q.S. al-Ankabu>t/29: 46.

$\Downarrow \overline{\mid \Upsilon} \mid \mu \rho \&\} \square \notin \delta(C \supset \Lambda \vee 9 \exists \exists \in / \square \omega \in) \supset=\approx \tau \Gamma \oplus 6) 9 \exists \# \square \cong \mid \delta \rho \&(\#) \theta^{\text {TM9 }} \notin \square \approx \pi \gamma\lceil\mathrm{B} \square \omega 0 \rho *$

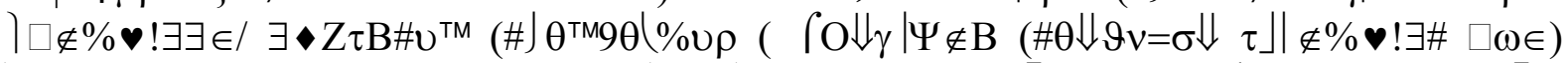

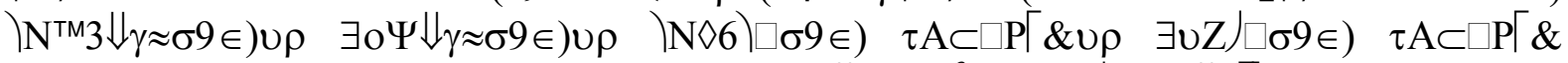
$\cap \subseteq \notin \cup \tau \beta \theta \downarrow \vartheta \in=\Upsilon \Upsilon \odot \mathrm{B} \ldots . . \mid \mu \sigma 9 \Downarrow \tau_{\tau \omega Y} \cup \rho(\subset \square \notin \nu \equiv \cup \rho$

Dan janganlah kamu berdebat dengan ahli kitab, melainkan dengan cara yang paling baik, kecuali dengan orang-orang zalim di antara mereka, dan katakanlah: "kami telah beriman kepada (kitab640.

${ }^{29}$ Departemen Agama, Al-Qur'an dan Terjemah Departemen Agama dengan Transliterasi Arab-Latin h.

\footnotetext{
${ }^{30}$ Departemen Agama, Al-Qur'an dan Terjemah Departemen Agama dengan Transliterasi Arab-Latin.
} h. 970 . 
kitab) yang diturunkan kepada kami dan yang diturunkan kepadamu; Tuhan kami dan Tuhanmu adalah satu; dan Kami hanya kepada-Nya berserah diri". ${ }^{31}$

5) Al-Qur'an menegaskan kepada manusia bahwa tidak ada paksaan dalam memeluk agama. Kemudian dalam Q.S. Yunus/10: 99 disebutkan "dan jikalau Tuhan menghendaki, tentulah beriman semua orang yang ada di bumi seluruhnya. Apakah kamu (hendak) memaksa manusia supaya menjadi orang-orang yang beriman semuanya."

Paparan di atas menunjukkan adanya landasan teologis normatif untuk menegakkan ukhuwah baik antar sesama muslim maupun mereka yang bukan muslim di lembaga pendidikan Yapis Papua. Persoalannya sekarang adalah bagaimana masalah ukhuwah ini dapat dipraktikkan pada tataran empirik di kalangan umat beragama yang belajar dan menuntut ilmu lembaga pendidikan tersebut.

Dasar toleransi beragama dalam pendidikan agama Islam yang diajarkan diharapkan dapat membutuhkan manusia yang memiliki mentalitas matang serta dewasa dan mampu mengendalikan emosinya. Di bidang keagamaan, kita selalu menemukan bahwa orang-orang yang bersikap paling toleran terdiri dari mereka yang sadar serta kokoh dalam memegang keyakinannya. Intoleransi biasanya muncul pada orang-orang yang memiliki pengetahuan agama tidak sempurna dan fragmentaris, yang membuatnya menjadi cepat emosional dan apologis. $^{32}$

Pengalaman ini sebenarnya mirip dengan pemikiran yang muncul pada permulaan gerakan pencerahan ketika kondisi-kondisi masyarakat semacam itu hanya dapat diharapkan kemunculannya bila anggota-anggotanya bermental bebas dan dewasa. Untuk mencapai tujuan tersebut dibutuhkan pendidikan, sehingga sistem persekolahan untuk umum pun dibangun. Hal yang sama juga dapat dianalogikan dengan agama-agama. Tanpa ajaran-ajaran agama yang komprehensif dan non-apoligetis, seruan terhadap perlunya toleransi beragama akan tetap dipandang sebagai seruan di padang pasir. Seseorang yang terdidik bisa saja berfikir sempit dan fanatik. Pendidikan tidak harus diartikan sebagai akumulasi ilmu pengetahuan. Pendidikan harus diberi tambahan dengan pembinaan, sebagai upaya untuk memperoleh formasi dari watak yang mampu menerima dan berfikir luas untuk mengadopsi sikap saling memahami dan saling toleran. Apa yang bisa dilakukan pendidikan agama Islam adalah mempersiapkan serta mengajarkan sikap yang menjamin kebebasan beragama dan mengawasi pelaksanaannya. Sama halnya, pendidikan agama memiliki tanggung jawab dalam mendorong berkembangnya toleransi.

\footnotetext{
${ }^{31}$ Departemen Agama, Al-Qur'an dan Terjemah Departemen Agama dengan Transliterasi Arab-Latin. h. 793.

${ }^{32}$ Lihat Muhammad Tholhah Hasan, Islam dalam Perspektif Sosio Kultural (Cet. 1; Jakarta: Lantabora Press, 2005), h. 293.
} 
Lembaga pendidikan Yapis Papua dapat serta memiliki kekuatan untuk mengatasi gejolak-gejolak yang timbul dalam masyarakat yang dapat merusak kerukunan antarumat beragama dan kehidupan beragama. Di antaranya dapat dikemukakan:

1) Kita memiliki Pancasila dan UUD 1945 yang menyatakan Negara Pancasila bukan negara agama ataupun sekuler.

2) Masih kuat kesadaran masyarakat untuk beragama. Pelajaran agama yang diberikan di sekolah dasar sampai perguruan tinggi meningkatkan usaha menganut agama secara sadar

3) Pemerintah RI. memiliki departemen agama yang melindungi dan membina kehidupan beragama. Di samping itu terdapat pula wadah musyawarah antar umat beragama yang diharapkan dapat menjaga dan memantapkan kerukunan hidup beragama.

4) Ekonomi masyarakat meningkat, dengan demikian kesenjangan ekonomi tidak bergeser ke arah kesenjangan agama

5) Terdapat kode etik penyiaran agama yang dikeluarkan oleh departemen agama dan peraturan pemerintah untuk menjaga kerukunan hidup beragama

Dalam konteks masyarakat Indonesia yang pluralistik, dalam arti masyarakat yang serba plural, baik dalam agama, ras, etnis, dapat menimbulkan konflik-konflik sosial. Pendidikan Agama dalam kehidupan masyarakat plural dapat berperan sebagai faktor pemersatu (integratif), dan dapat pula berperan sebagai faktor pemecah (disintegratif). Fenomena semacam ini akan banyak ditentukan setidak-tidaknya oleh: (1) dokrin dan teologi ajaran agama; (2) pemahaman dan sikap serta perilaku pemeluk agama; (3) lingkungan sosiokultural yang mengelilinginya; serta (4) peranan guru dan pengaruh pemuka agama.

\section{Pembelajaran PAI tentang Pendidikan Toleransi Hidup Beragama}

\section{Hakikat Pembelajaran PAI}

Slameto mengatakan belajar sebagai proses perubahan tingkah laku. ${ }^{33}$ Oemar Hamalik berpendapat bahwa pembelajaran adalah suatu kombinasi yang tersusun meliputi unsur-unsur manusiawi, materil, fasilitas, perlengkapan dan prosedur yang saling mempengaruhi untuk mencapai tujuan pembelajaran. ${ }^{34}$

Berbagai pendekatan yang dapat digunakan dalam pembelajaran adalah :

a. Pendekatan pengalaman, yaitu pemberian pengalaman keagamaan kepada siswa dalam rangka penanaman nilai-nilai keagamaan.

${ }^{33}$ Slameto, Belajar dan Faktor-faktor yang mempengaruhinya (Jakarta: Rineka Cipta, 2003), h. 45.

${ }^{34}$ Lihat Oemar hamalik, Kurikulum dan Pembelajaran (Cet. 4; Jakarta: Bumi Aksara, 2008), h. 57. 180 | IQ (Ilmu Al-qur'an): Jurnal Pendidikan Islam | Volume 2 No. 022019 
b. Pendekatan pembiasaan, yaitu memberi kesempatan kepada siswa untuk senantiasa mengamalkan ajaran agama dalam kehidupan sehari-hari.

c. Pendekatan emosional, memahami, dan menghayati ajaran agamanya dengan tujuan agar perasaan siswa bertambah kuat terhadap keagamaannya kepada Allah swt.

d. Pendekatan rasional, yaitu usaha memberikan peranan kepada rasio atau akal dalam memahami dan menerima kebenaran ajaran agama serta mencoba menggali hikmah dan fungsi ajaran agama.

e. Pendekatan fungsional, yaitu penyajian materi ajaran agama Islam dengan penekanan pada segi pemanfaatan bagi siswa kehidupan sehari-hari sesuai tingkat perkembangan siswa itu sendiri.

f. Pendekatan keteladanan, yaitu menyuguhkan keteladanan, baik langsung melalui kondisi penciptaan yang baik di lingkungan sekolah, maupun tidak langsung, melalui penciptaan yang baik di lingkungan sekolah, maupun tidak langsung, melalui suguhan ilustrasi berupa kisah-kisah keteladanan.

\section{Pembelajaran Toleransi Hidup Beragama di Yapis Papua}

Jika ditilik dari aspek program dan praktik pendidikan yang dilaksanakan, maka seluruh pendidikan Islam di Indonesia yang ada saat ini setidak-tidaknya dapat dibagi ke dalam 5 (lima) jenis, yaitu (1) pendidikan pondok pesantren; (2) pendidikan madrasah, yang saat ini disebut sebagai sekolah umum yang berciri khas Islam, dan pendidikan lanjutannya seperti IAIN/STAIN atau perguruan tinggi Islam yang bernaung di bawah departemen agama; (3) pendidikan umum yang bernafaskan Islam, yang diselenggarakan oleh dan/atau berada di bawah naungan yayasan dan organisasi Islam; (4) pelajaran agama Islam yang diselenggarakan di lembaga-lembaga pendidikan umum sebagai suatu mata pelajaran atau mata kuliah saja. dan (5) pendidikan Islam dalam keluarga atau di tempat-tempat ibadah, dan/atau di forum-forum kajian keislaman, majelis taklim dan sebagainya yang sekarang sedang digalakkan oleh masyarakat.

Pembelajaran pendidikan agama Islam di lembaga pendidikan Yapis Papua dalam kelima konteks jenis pendidikan Islam tersebut termasuk jenis yang keempat.

Kurikulum pendidikan agama Islam di sekolah yang pada akhirnya ingin mewujudkan penciptaan suasana religius di sekolah. ${ }^{35}$ Pembelajaran pendidikan agama Islam pada dasarnya hendak mengantarkan siswa agar memiliki: (1) kemantapan akidah dan kedalaman spiritual;

\footnotetext{
${ }^{35}$ Muhamin et. al., Paradigma Pendidikan Islam: Upaya Mengektifkan Pendidikan Agama Islam di Sekolah (Cet. 4; Bandung: Remaja Rosdakarya, 2008), h. 104.
} 
(2) keunggulan akhlak; (3) wawasan pengembangan dan keluasan iptek; dan (4) kematangan profesional. Tugas pendidikan agama Islam di sekolah selama ini terutama pada aspek pertama dan kedua; namun demikian, bagaimana menjadikan aspek ketiga dan keempat sebagai perwujudan dari pengalaman siswa, sebaliknya pengembangan aspek ketiga dan keempat diwarnai dan dijiwai oleh aspek pertama dan kedua. Inilah tantangan yang dihadapi oleh guru agama dan sekaligus pesan-pesan besar pendidikan Islam yang harus diperjuangkan dalam mengembangkan atau mengaktua-lisasikan kurikulum pendidikan agama Islam di sekolah umum. Tentu tidak lepas dari sikap siswa akan toleransi beragama, sebagai umat beragama yang dituntut untuk dapat menghargai umat beragama lain sebagai bentuk toleransi sesama manusia yang beriman kepada Tuhan...

\section{Materi PAI di Lembaga Pendidikan Yapis Papua}

Materi ajar PAI dalam kurikulum 2006 tentang standar isi terdiri dari lima aspek, yakni aspek Al-Qur'an dan hadis, akidah, akhlak, fikih, tarikh dan kebudayaan Islam. Pengembangan lima aspek tersebut didasarkan atas tiga ranah yakni ranah kognitif, afektif dan psikomotor. Ranah Kognitif, jika kompetensi yang ditetapkan meliputi mengingat, memahami, menerapkan, menganalisis, mengevaluasi dan menciptakan. Ranah Psikomotor jika kompetensi yang ditetapkan meliputi gerakan meniru, gerakan manipulasi, gerakan melakukan dengan prosedur, Gerakan melakukan dengan baik dan tepat, gerakan melakukan tindakan secara alami. Ranah Afektif jika kompetensi yang ditetapkan meliputi menerima, merespon, menghargai, mengorganisasikan dan karakterisasi menurut nilai (internalisasi).

Penjelasan guru PAI kepada peserta didik, maka tentu yang kita inginkan adalah peserta didik bukan hanya mengerti tetapi juga dapat melaksanakan praktek-praktek ajaran Islam baik yang bersifat pokok untuk dirinya maupun yang bersifat kemasyarakatan (sikap toleransi). Karena di dalam materi pendidikan agama Islam bukan hanya memperhatikan aspek penguasaan pengetahuan kognitif saja, tetapi juga sikap kepribadian dan tingkah laku peserta didik. Ketiga ranah tersebut harus termuat dalam kelima aspek materi ajar pendidikan agama Islam yaitu:

a. Al-Qur'an dan Hadis

Al-Qur'an dan hadis adalah bagian dari materi pelajaran pendididikan agama Islam yang memberikan pendidikan untuk memahami dan mengamalkan al-Qur'an sehingga mampu membaca dengan fasih dan menghafal ayat-ayat terpilih dan isi kandungannya dan mengamalkan hadis-hadis.

1) Fungsi 
Untuk mengarahkan pemahaman dan penghayatan pada isi yang terkandung dalam kehidupan sehari-hari, yaitu perilaku yang memancarkan iman dan takwa kepada sang Khalik sesuai dengan tuntutan Al-Qur'an dan hadis.

2) Tujuan

Bertujuan agar siswa memahami, meyakini dan mengamalkan isi kandungan ajaran AlQur'an dan hadis serta bergairah untuk membacanya dengan fasih dan benar.

b. Aqidah akhlak

Pendidikan aqidah akhlak adalah usaha yang dilakukan secara terencana dalam menyiapkan peserta didik untuk mengetahui, memahami, mendalami dan mengimani Allah swt. merealisasikannya dalam perilaku akhlak mulia dalam kehidupan sehari-hari melalui kegiatan bimbingan, pengajaran, latihan, penggunaan pengalaman, keteladanan dan pembiasaan. Dalam kehidupan masyarakat yang majemuk dalam bidang keagamaan, pendidikan ini juga pada peneguhan akidah di satu sisi dan peningkatan toleransi serta menghormati dengan penganut agama lain dalam rangka mewujudkan kesatuan dan persatuan. ${ }^{36}$

1) Mata pelajaran akidah akhlak berfungsi untuk:

a) Pemahaman nilai-nilai ajaran Islam sebagai pedoman mencapai kebahagiaan hidup dunia dan akhirat.

b) Pengembangan keimanan dan ketakwaan kepada sang Khalik

c) Penyelesaian mental siswa terhadap lingkungan fisik dan sosial melalui akidah akhlak.

d) Pengajaran tentang informasi dan pengetahuan keimanan dan akhlak serta sistem fungsionalnya

2) Tujuan pelajaran akidah akhlak untuk menumbuhkan keimanan peserta didik yang diwujudkan dalam akhlaknya yang terpuji melalui pemupukan, pengetahuan, pengamalan.

c. Fikih

Fikih adalah salah satu bagian materi pelajaran pendidikan agama Islam yang diarahkan untuk menyiapkan siswa untuk mengenal, memahami, menghayati, dan mengamalkan hukum Islam yang kemudian menjadi dasar pandangan hidupnya melalui bimbingan, pengajaran dan latihan.

1) Fungsi Fikih

\footnotetext{
${ }^{36}$ Departemen Agama RI, Kurikulum 2004 Standar Kompetensi (Jakarta: Direktorat Jenderal Kelembagaan Agama Islam), h. 21.
} 
Penanaman nilai-nilai dan kesadaran beribadah siswa kepada Allah swt. sebagai pedoman mencapai kebahagiaan hidup di dunia dan akhirat, untuk penanaman kebiasaan melaksanakan hukum Islam, pembentukan kedisiplinan dan pembinaan keimanan dan ketakwaan.

2) Tujuan Fikih

Mengetahui dan memahami pokok-pokok hukum Islam secara terperinci dan menyeluruh baik berupa dalil naqli dan aqli dan melaksanakan dan mengamalkan ketentuan hukum Islam dengan benar.

d. Sejarah Kebudayaan Islam

Sejarah kebudayaan Islam adalah salah satu bagian materi palajaran pendidikan agama Islam yang diarahkan untuk menyiapkan siswa untuk mengenal, memahami, dan menghayati sejarah kebudayaan Islam yang kemudian dijadikan pandangan melalui bimbingan, pengajaran, latihan, dan lain-lain.

1) Fungsi

Edukatif, menanamkan nilai, prinsip, sikap hidup yang luhur dalam Islam dan menjalankan kehidupan sehari-hari, keilmuan untuk mengetahui tentang masa lalu sejarah kebudayaan Islam.

2) Tujuan

Memberikan pengetahuan tentang sejarah kebudayaan Islam kepada siswa agar memiliki data yang obyektif dan sistematis tentang sejarah Islam, mengambil ibrah dan mengapresiasi nilai-nilai dan makna yang terdapat dalam sejarah, menanamkan penghayatan dan mengamalkan nilai-nilai Islam berdasarkan fakta sejarah dan membekali siswa untuk membentuk kepribadian melalui imitasi terhadap tokoh-tokoh teladan sehingga terbentuk kepribadian yang luhur.

Keempat materi pelajaran pendidikan agama Islam yang diberikan di lembaga pendidikan Yapis Papua di atas menjadi sangat penting dielaborasi dalam proses pembelajaran khususnya dalam meningkatkan toleransi hidup beragama.

Usaha pembelajaran pendidikan agama Islam di sekolah diharapkan agar mampu membentuk kesalehan pribadi dan sekaligus kesalehan sosial sehingga pendidikan agama diharapkan jangan sampai: (1) menumbuhkan semangat fanatisme; (2) menumbuhkan sikap intoleran di kalangan siswa dan masyarakat Indonesia; dan (3) memperlemah kerukunan hidup beragama serta persatuan dan kesatuan nasional. walhasil, pendidikan agama Islam diharapkan 
mampu menciptakan persaudaran sesama islam dalam arti luas, yaitu persaudaraan sesama agama, persaudaraan sesama anak bangsa, dan persaudaraan sesama umat manusia.

Karena itu, pembelajaran pendidkan toleransi hidup beragama di lembaga pendidikan Yapis Papua mampu mewujudkan ukhuwah Islamiyah dalam arti luas tersebut. Sungguhpun peserta didik yang menuntut ilmu itu berbeda-beda agama, ras, etnis, tradisi, dan budaya, tetapi bagaimana melalui keragaman ini dapat dibangun suatu tatanan hidup yang rukun, damai dan tercipta kebersamaan hidup serta toleransi yang dinamis dalam membangun Papua khususnya mempererat rasa persaudaraan sesama anak bangsa di dalam menjaga keutuhan negara kesatuan republic Indonesia.

Pendidikan sikap toleransi hidup beragama dalam lingkup lembaga pendidikan khususnya di sekolah yang berada di bawah naungan Yapis Papua dibutuhkan sebagai ikatan keadaban (the bound of civility), yakni pergaulan antara satu sama lain, satu peserta didik dengan peserta didik lainnya yang diikat dengan suatu keadaban. Ikatan ini pada dasarnya dapat dibangun dari nilai-nilai universal ajaran agama. karena itu, bagaimana guru pendidikan agama mampu membelajarkan pendidikan agama yang difungsikan sebagai panduan moral sikap toleransi dalam kehidupan masyarakat yang serba plural tersebut bukan saja untuk siswa yang beragama Islam namun juga kepada siswa yang non Islam, mampu mengangkat dimensidimensi konseptual dan substansial dari ajaran agama, kesadaran akan hak dan kewajiban seperti sikap toleransi, keadilan, kebersamaan, kejujuran, ketulusan dalam beramal, musyawarah dan sebagainya, untuk diaktualisasikan dan direalisasikan dalam hidup dan kehidupan masyarakat yang majemuk.

Di dalam ajaran agama Islam terdapat suatu pandangan yang universal, yaitu bahwa manusia diciptakan oleh Allah sebagai makhluk yang terbaik dan tertinggi/termulia (QS. AlTin/ :4 dan QS. Al-Isra/ :70, serta diciptakan dalam kesucian asal (fitrah) sehingga setiap manusia mempunyai potensi benar. Di sisi lain, manusia juga diciptakan oleh Allah sebagai makhluk yang dhaif (QS. Al-Nisa'/4: 28, sehingga setiap manusia mempunyai potensi salah.

Dimensi-dimensi ajaran agama baik yang vertikal maupun horizontal, semuanya harus termuat dan tercakup dalam pengertian pendidikan agama, untuk tidak sekedar membentuk kualitas dan kesalehan individu semata, tetapi juga sekaligus kualitas dan kesalehan sosial, serta kesalehan terhadap alam semesta.

a. Toleransi dalam Materi Pendidikan Agama Islam kelas XII

Toleransi dalam materi pendidikan agama Islam di sekolah yang dirumuskan oleh departemen agama adalah materi yang diajarkan di sekolah menengah atas dan sekolah menengah kejuruan berada pada kelas XII semester 1 disebutkan standar kompetensi dari aspek 
Al-Qur'an yaitu memahami ayat-ayat Al-Qur'an tentang anjuran bertoleransi dengan kompetensi dasarnya, pertama membaca Q.S. al Kafirun/109: 1-6, Q.S. Yunus/10: 40-41, dan Q.S. al-Kahfi/18: 29, kedua menjelaskan arti Q.S. al Kafirun/109: 1-6, Q.S. Yunus/10: 40-41, dan Q.S. al-Kahfi/18: 29, ketiga membiasakan perilaku bertoleransi seperti terkandung dalam Q.S. al Kafirun/109: 1-6, Q.S. Yunus/10: 40-41, dan Q.S. al-Kahfi/18: $29^{37}$

\section{Kesimpulan}

Sesuai dengan tujuan dari pendidikan agama Islam adalah adanya perubahan perilaku dan sikap serta kuantitas dan kualitas seseorang, maka pembelajaran harus berlangsung sedemikian rupa sehingga tidak sekedar menyampaikan informasi keagamaan dan moral kepada peserta didik melainkan perlu untuk menyentuh hati dan mendorong hasrat peserta didik untuk bisa mengambil keputusan berubah, dan menerapkannya di dalam kehidupannya. Prinsip di dalam kehidupan menuntut ilmu sepanjang hidup atau long life education, pendidikan agama Islam harus dapat dan mampu menjiwai pada tingkat kesadaran yang dalam pada diri peserta didik. Di samping bertujuan memperkuat keyakinan keagamaan, pendidikan yang berbasis pada toleransi hidup beragama juga harus diorientasikan pada penanaman simpati, empati dan solidaritas sesama, menjadikan mereka adalah bagian yang tidak terpisahkan di dalam kehidupan sehari hari.

\section{Saran}

Penulisan hasil penelitian yang dilakukan ini terkait dengan penerapan pembelajaran pendidikan agama Islam di lembaga pendidikan Yapis Papua Jayapura kepada siswa yang majemuk dari ras, suku dan agama. Saran akademik untuk penelitian berikutnya agar mendalami suasana kebatinan peserta didik yang mayoritas non muslim yang belajar pendidikan agama Islam di lembaga pendidikan Yapis Papua Jayapura, secara kelembagaan lembaga pendidikan ini adalah lembaga pendidikan yang berciri khas agama Islam namun peserta didik agama Islam menjadi minoritas, karena penulis belum mendalami sampai sejauh itu.

${ }^{37}$ Syaeful Hadi dan Sholihah, Pendidikan Agama Islam untuk SMA atau MA Semester Gasal sesuai Kurikulum KTSP (Hayati: Solo, 2006), h. 186 | IQ (Ilmu Al-qur'an): Jurnal Pendidikan Islam | Volume 2 No. 022019 


\section{Daftar Pustaka}

al-Ishfahani>, al-Raghib. Mu'jam Mufradat alfazh al-Qur'an (Beirut: Da>r al-Fikr, tth. an-Nahlawi, Abdurrahman. Pendidikan Islam di Rumah, Sekolah dan Masyarakat. Jakarta: Gema Insani, 2005.

Assegaf, Abd. Rachman. Filsafat Pendidikan Islam. Cet. 1; Jakarta: PT RajaGrafindo Persada, 2011.

Baharuddin dan Moh. Sakin, Pendidikan Humanistik. Ar-Ruzz Media: Jogjakarta, 2007.

Berlin, Isiah. On Pluralism, New York Review of Books, Volume 14., Number 8, 1998.

Daradjat, Zakiah. Ilmu Pendidikan Islam (Cet. 9; Jakarta: Bumi Aksara, 2011.

Daulay, Haidar Putra. Pendidikan Islam. Jakarta: Kencana, 2004.

Departemen Agama RI, Kurikulum 2004 Standar Kompetensi (Jakarta: Direktorat Jenderal Kelembagaan Agama Islam.

Departemen Agama RI. Dirjen Kelembagaan Agama Islam Ditpais, Pedoman Pendidikan Agama Islam untuk Sekolah Umum. Jakarta: Diptais, 2004.

Departemen Agama, Al-Qur'an dan Terjemahnya dengan Tranliterasi Arab-Latin.

Diana L. Eck, A New Religious America: How a Christian Country: Has Become the Words Most Religiously Diverse Nation. New York: Harper San Fransisco, 2001.

Hadi, Syaeful dan Sholihah, Pendidikan Agama Islam untuk SMA atau MA Semester Gasal sesuai Kurikulum KTSP. Hayati: Solo, 2006.

hamalik, Oemar. Kurikulum dan Pembelajaran. Cet. 4; Jakarta: Bumi Aksara, 2008.

Hasan, Muhammad Tholhah. Islam dalam Perspektif Sosio Kultural. Cet. 1; Jakarta: Lantabora Press, 2005.

Hasbullah. Dasar-dasar Ilmu Pendidikan. Ed. Revisi; Jakarta: PT Raja Grafindo Persada, 2009.

Kaukal Ismail. Tagayyur al-Ahka>m fi al-Syari>ah al-Isla>miyyah. Beirut, Muassasah AlRisalah, 2000.

Kuntowijoyo. Identitas Politik Umat Islam. Cet. 2; Bandung: Mizan, 1997.

Liustia, dkk. Problematika Pendidikan Agama di Sekolah, Hasil penelitian tentang Pendidikan Agama di Kota Jogjakarta, 2004-2006. Jogjakarta: Interfedei, 2007.

Misrawi, Zuhairi. Al-Qur'an Kitab Toleransi: Tafsir Tematik Islam Rahmatan Lil Alamin. Cet. 1; Jakarta: Gramedia Widiasarana, 2010.

Muchsin M. Bashori. dkk., Pendidikan Islam Humanistik. Cet. 1; Bandung: Refika Aditama, 2010. 
Hasrudin Dute

Muhaimin, Nuansa Baru Pendidikan Islam: Mengurai Benang Kusut Dunia Pendidikan. Cet. 1; Jakarta: RajaGrafindo Persada, 2006.

Muhamin et. al., Paradigma Pendidikan Islam: Upaya Mengektifkan Pendidikan Agama Islam di Sekolah. Cet. 4; Bandung: Remaja Rosdakarya, 2008.

Mujib, Abdul dan Jusuf Mudzakir. Ilmu Pendidikan Islam. Cet. 1; Jakarta: Prenada Media, 2006.

Nata, Abuddin. Ilmu Pendidikan Islam. Cet. 1; Jakarta: Prenada Media Group, 2010.

Nurhakim, Moh. Islam Responsif: Agama di Tengah Pergulatan Ideologi Politik dan Budaya Global. Cet. 1; Malang: UMM Press, 2005.

Purwanto, Wawan H. Papua 100 tahun Ke Depan (Cet. 1; Jakarta: Cipta Mandiri Bangsa, 2010.

Shihab, M. Quraish. Membumikan al-Qur'an. Bandung: Mizan, 2002.

Sidi, Indra Djati. Menuju Masyarakat Belajar Menggagas Paradigma Baru Pendidikan (Jakarta: Paramadina, 2001.

Simuh dkk., Islam dan Hegemoni Sosial. Cet. 1; Jakarta: Mediacita, 2001.

Slameto, Belajar dan Faktor-faktor yang mempengaruhinya (Jakarta: Rineka Cipta, 2003.

Sudjangi, "Pluralitas Sosial, Hubungan Antar Kelompok Agama dan Kerukunan" Harmoni: Jurnal Multikultural dan Multireligius, Vol. 2 No. 5, Puslitbang Kehidupan Beragama Depag RI, Jakarta 2003.

Suwarno. Pengantar Umum Pendidikan. Jakarta: Aksara Baru, 1985.

Tim Dosen FKIP-IKIP Malang, Pengantar Dasar-Dasar Pendidikan. Surabaya: Usaha Nasional, 1988.

UU RI. No.20 tahun 2003, Sistem Pendididikan Nasional. Cet. 2; Bandung: Citra Umbara, 2010.

Wehr, Hans. Mu'jam al-Lughah al-Arabiyah al-Mu'asharah (A Dictionary of Modern Written Arabic) (Beirut Librarie Du Liban \& London: Macdonald \& Evans LTD, 1974.

Zuhairini, dkk., Filsafat Pendidikan Islam. Cet. 5; Jakarta: Bumi Aksara, 2010. 